\title{
I CAN FLY
}

\section{Juxtaposition lärarutbildare - klasslärarstuderande Konstbaserade lärprocesser som bildkonstdidaktisk erfarenhet}

\author{
Hannah Kaihovirta* \\ Åbo Akademi, Helsingfors universitet
}

\begin{abstract}
Abstrakt
Den här artikeln beskriver och undersöker konstbaserade lärprocesser. Artikeln består av två perspektiv som står i juxtaposition till varandra. Det ena perspektivet består av mina upplevelser och erfarenheter som konstnär och lärarutbildare. Det andra perspektivet består av dokumentation av de lärprocesser och upplevelser som lärarstuderande artikulerat i en konstbaserad kurs som jag hållit inom det pedagogiska vetenskapsområdet bildkonstens didaktik. Artikelns metodologiska ansats är transformativa lärprocesser i lärande som deltagarkultur. Det här betyder att de studerande som deltar i kursen som beskrivs är medaktörer, medskapare och utvecklare av forskningsprocessens resultat. Artikelns syfte är att förstå hur konstbaserade lärprocesser kan komma till uttryck som lager på lager av konstupplevelser som transformeras till konstdidaktisk medvetenhet hos lärarstuderande. I sin helhet diskuteras om konstbaserade lärprocesser kan uttryckas och kommuniceras som konst som erfarenhet då det är en del av pedagogiskt utvecklingsarbete i lärarutbildning. Artikeln strävar till att syntetisera hur konst- och didaktisk medvetenhet i förlängningen skapar levande bildkonstdidaktik. Artikelns resultat förväntas bidra till förståelse för hur klasslärarstuderande uttrycker möjlig professionell lärarkompetens i bildkonstens didaktik i form av egenmakt och delaktighet i konstupplevelser och hur de beskriver konst som möjlighet i lärande.
\end{abstract}

Nyckelord: konstbaserade lärprocesser; bildkonstens didaktik;juxtaposition; autoetnografi; deltagande forskningspraktik

\begin{abstract}
EN)
This article describes and examines art-based learning processes. The article consists of two perspectives that stand in juxtaposition to each other. One perspective consists of my experiences as an artist and teacher educator together with class teacher students. The second perspective consists of documentation of the learning processes and experiences that teacher students articulated in an art-based course in visual art didactics. The article's methodological approach is transformative learning in participatory processes. This means that the students who share the course
\end{abstract}

^Korrespondanse: Hannah Kaihovirta, Pedagogiska fakulteten, FI 00014 Helsingfors universitet. Epost: hannah.kaihovirta@helsinki.fi 
are co-workers, co-creators and developers of the research results. The purpose of the article is to understand how art-based learning processes can be expressed as layers of artistic experiences that result in an art didactic awareness of teacher students. In its entirety, I discuss whether art-based learning processes can be expressed as developmental work in teacher education and how teacher students' learning can be communicated as art as experience. The article aims to synthesize how art and didactic awareness together creates vivid art education. The article's results are expected to contribute to an understanding of how teacher students express possible professional teacher skills in visual arts and how teacher students describe art as an opportunity for learning.

Key words: Arts-based learning processes; visual art education;juxtaposition; autoethnography; participatory action research

Received: May, 2017; Accepted: January, 2018; Published: March, 2018

I konsten fungerar symboler som vaga syftningar, inte som direkta beteckningar av något. ${ }^{1}$

Hur kan ett påstående av det här slaget om ett fenomen som inte följer en på förhand given båge av systematik överhuvudtaget sammanföras med vetenskap? Det här är en fråga som å ena sidan ger möjlighet till överblick och sammanhang då det kommer till vad som händer då konst och vetenskap möts genom sina respektive villkor och diskurser. Å andra sidan skapas rum för att observera vad konst är i förhållande till andra kulturfält. Konstens och vetenskapens karaktärer beskrivs traditionellt genom konstens eller vetenskapens kvaliteter.

Då det kommer till konsten som praktik och vetenskapen som praktik överlappar konst och vetenskap varandra i själva görandet. Det här blir ofta explicit synligt i mitt praktiska arbete med lärarstuderande, framförallt i konstnärliga och estetiska lärprocesser. Till exempel är ett särdrag som kan kännas igen genom konstens och vetenskapens linser de studerandes ivriga intresse för och förmåga att arbeta i processer som sträcker sig utöver det förväntade i en kurs. Jag handleder ofta i kurserna genom att visa på att konst och vetenskap utöver systematik, kunskapsmål och resultatmål omfattar ett av bildningens starka men öppna mål - att växa som människa.

I den här artikeln artikulerar jag genom att kombinera text- och bilddokumentation hur och i vilka syften jag bygger upp konstnärlig och konstdidaktisk medvetenhet hos lärarstuderande. I artikeln växlar jag mellan olika positioner av vetenskaplig systematik; jag prövar min egen lärarröst, min konstnärsröst och min forskarröst i relation till studeranderöster. Jag prövar min röst mot vetenskapens röst, jag prövar visuella avtryck, hur de berikar rösten. Det är en form av artikelns interna polyfoni. Jag tänker att formen skapar resonans och klangbotten för att prövas, granskas och utvecklas på nytt och på nytt. För att skapa artikeln har jag dokumenterat en görandeprocess, där själva görandet är flera tolkningar av erfarenheter.

Under forskningsprocessen med materialet har jag fått syn på och fått möjlighet att analysera och tolka mönster i den didaktik jag använder mig av. Genom processen

${ }^{1}$ Författerens översättelse av citat "In the arts, symbols adumbrate; they do not denote." (Barone \& Eisner, 2012, s.2) 


\section{H. Kaihovirta}

har jag fått en tydligare syn på hur jag arbetar som konstnär, forskare och lärare och hur jag kan skapa än mer artikulerat och nyanserat sätt att kommunicera med studerande om konst, didaktik och lärande.

\section{Konst, bildning och grundutbildning}

Frågan om det går att sammanföra konst och vetenskap kan besvaras på många sätt. Ett svar på frågan är att om konsten uppenbarar en ontologi som uttrycker det vaga - så uttrycker vetenskap - eller snarare forskning som vetenskaplig disciplin en ontologi som är uppbyggd kring medvetenheten om att så exakt och systematiskt som möjligt beskriva och undersöka ett fenomen. Ett annat svar på frågan är att "direkta beteckningar" av symboler, då det kommer till att förstå symbolernas betydelse för människan, inte nödvändigtvis skapar mer fungerande förutsättningar för att skapa mening än "vaga syftningar" (Jf. Barone \& Eisner, 2012). Människan prövar på kända och oväntade betydelser då de kommunicerar och använder olika symboler. Resonemanget för aktivt tanken vidare och öppnar för flera frågor. En fråga som dyker upp i sammanhanget är: vad innebär det "att skapa mening"?

Processen med att skapa mening tar sin början i människans behov av att förstå. Att skapa mening handlar i stort om att försöka greppa ett logiskt samband i det människan möter, tolka det utgående från den erfarna referensram individen har, kommunicera den med andra och skapa mening. Då det kommer till symboler (som semiotiskt har ett mer specifikt betydelsebärande fält än till exempel tecken) handlar det om att människan lärt sig det sammanhang där symboler har betydelse och mening. I möten med konstens vaga syftningar så händer något essentiellt. Symbolernas sammanhang kan vara väntat eller helt oväntat. Människor blir i mötet med konst uppmärksamma på konstens sätt att hantera det som är bekant. Konsten skapar i sig själv en situation där människan reagerar, väcks till att kommunicera och ge respons. I många sammanhang leder behovet till viljan att tillsammans med andra kommunicera, känna igen och bli uppmärksam på nya sätt att förstå (Jf. Barone \& Eisner, 2012). Meningsskapande innebär i sammanhanget att lära sig något genom att tolkningar av situationer, artefakter, fenomen händelser ställs i förhållande till tidigare erfarenheter och referenser. Lärandet kan utöver det kognitiva, kännas i hela kroppen som en förändring som omfattar processer av identitetsskapande, känslor och omvärdering av kända mönster och resurser.

Den erfarenhet jag har som konstnär och forskare formas i stor utsträckning av kulturfältet utbildning. Därför kan det i sammanhanget förstås som givet att välja utbildning som en mötesplats för konst och vetenskap. Det pedagogiska vetenskapsområdet erbjuder en kunskapssyn - system och strukturer - där lärande ställs i förhållande till att undervisa. Spänningsfältet mellan att lära och undervisa öppnar från konstens perspektiv intressanta möjligheter att ta tag i, eftersom konsten artikulerar och synliggör, ofta med öppna mål, medan undervisning förverkligas med tydliga mål. 
Jag känner igen mitt arbete i ett pragmatiskt förhållningssätt i den utsträckning pragmatism förstås som en teori om mening och sanning $i$ skapandeprocesser. Utmaningen i mitt arbete ligger $i$ att jag genom undervisningen tillsammans med de studerande prövar idéer, teorier och förförståelse. Om något av det som prövas fungerar på ett fruktbart sätt i en konstbaserad lärsituation (som är laddad med estetiska kvaliteter) är det av mindre betydelse om upplevelsen just då är vetenskapligt sann. Kvaliteten som kan visa sig är oväntad, en upplevelse som blir till erfarenhet i processen, och kan leda till helt nya sätt att förstå kunskap. Just den här processen är svår att artikulera.

Lärande som process har givetvis betydelse för hur jag närmar mig forskningsansats, -tema, -material (data) och -metod. Jag har i arbetet som lärarutbildare lärt mig mycket om hur konst, forskning och undervisning blir något mer än förväntat. Inom lärarutbildning kommunicerar lärarstuderande inte endast den ämneskunskap de breddar och fördjupar under kurser. Under de kurser och föreläsningar jag arbetar med undersöker deltagarna konstnärliga uttryck, för didaktiska samtal om sina erfarenheter och lärprocesser. Lärarstuderande responderar ofta genom att säga att "kurserna är fulla av liv" och med stor tillit använder de och delar med sig av sina livserfarenheter då de prövar konstnärliga uttryck. De uttrycker bildning i bemärkelsen att känna igen den som en förmåga att skapa konstnärliga erfarenheter och kommunicera dem med andra. De här erfarenheterna skapar i mig som konstnär, forskare och lärarutbildare en form av kumulativ erfarenhet (Jf. Leavy, 2015) som jag behöver artikulera och kommunicera. Konstnärliga uttryck kan i viss utsträckning också erbjuda mig redskap till att omforma mina erfarenheter av arbetet med lärarstuderande till nya uttryck, till nya konstbaserade lärsituationer, lärmiljöer och lärprocesser. Därutöver behöver jag den pedagogiska vetenskapens förhållningssätt, språk, system och dispositioner för reflektion. Det här för att artikulera ny kunskap, nya teorier och nya metoder för att förstå de komplexa lager av kunskap som processerna genererar. Pedagogikens språk ger mig redskap att visa respekt för de lärprocesser som studerande erfar. Forskningsetiskt strävar jag till att hela tiden vara medveten om att varje sätt jag väljer att artikulera ny kunskap på också innehåller det jag inte artikulerar, observerar eller reflekterar över.

En av de stora utmaningarna $\mathrm{i}$ att arbeta med konstbaserade lärprocesser med lärarstuderande är att på ett kvalitativt sätt föra fram möjligheten att förstå hur konstbaserade lärprocesser kan tillföra mening i undervisning. Klasslärarstuderande studerar pedagogik som huvudämne och i deras studier ingår en mycket bred palett av ämnesdidaktiska studier som ger dem goda redskap för att arbeta med grundutbildning och allmänbildning. Min erfarenhet är att lärarstuderande behöver få både erfarenhet, begrepp och praktik för att kunna artikulera sig som "agenter" för bildning. Därför måste framförallt lärarutbildning handla om något mer än att endast socialiseras in i en bildningskultur och verksamhet. Klasslärarstuderande behöver ha ett dubbelt perspektiv då de genomgår sin utbildning. Å ena sidan behöver de få 


\section{H. Kaihovirta}

redskap för pedagogisk metareflektion över sin professionsutveckling. Samtidigt ska de skapa sig ett metaperspektiv så att de kan förhålla sig till andras lärande och olika discipliner.

I International Handbook of Teacher education (Loughran \& Hamilton, 2016) framkommer det att lärare i sitt arbete alltid hoppas på att det finns ett bra och direkt förhållande mellan undervisning och lärande. Av någon anledning finns det en vana att i lärarutbildning förenkla det här förhållandet till en lineär process om hur lärare ska agera i klassrummet. En alltmer breddad och fördjupad forskning på området visar att förhållandet mellan att lära sig undervisa, att förstå vad det innebär och hur det förhåller sig till lärande är en komplex och mångfasetterad lärprocess (Loughran \& Hamilton, 2016).

Som lärarutbildare arbetar jag med att pröva teorier, metoder, erfarenheter och strategier för att konsten ska ha betydelse för de lärarstuderande då det kommer till att förstå undervisning och lärande som bildning. Det här är en utmaning då konstfältet hela tiden förändras och omfattar både vaga syftningar, konkreta uttryck och kommunikativa handlingar. Georgina Barton och Margaret Baguley (2017) beskriver i en nyutgiven handbok om global konstundervisning hur det fortsättningsvis är problematiskt att konstundervisning inte självklart värdesätts eller är systematiskt framfört i utbildningsfältets institutionella policy- och verksamhetsdokument. Det här trots att konstens betydelse för lärande, motivation och delaktighet är väldokumenterad och omfattar en bred forskarpraktik (Jf. Barton \& Baguley, 2017). Under 2000-talet har problematiken blivit uppmärksammad på flera sätt. 2006 sammanställde Anne Bamford rapporten The Wow Factor. Samma år publicerade UNESCO Road Map to Arts Education. 2013 utkom OECD med rapporten Arts for Art's Sake (Winner, Goldstein, og Vincent-Lancrin, 2013). Rapporterna har givetvis betydelse för hur konst, forskning och utbildning artikuleras och sammanlänkas för en hållbar praktik. I Finland har bildkonsten en solid plats inom allmänbildande grundutbildning eftersom Bildkonst är ett obligatoriskt ämne i grundskolan (till årskurs 7). Ämnet bildkonst är även en obligatorisk kurs i klasslärarnas studier i Finland. Ämnet ges betydelse i ett samhällsperspektiv, ett kulturperspektiv och ett individperspektiv. Det här synliggörs tydligt i nationella policy- och verksamhetsdokument, såsom läroplan. I dokumenten finns inbäddat det som är självklart och samtidigt utmanande i lärande, undervisning, didaktik och framförallt konstdidaktik, människans vilja att förstå sin existens, att artikulera den i att det finns en mening med det jag gör och det att jag finns, för mig som individ, $i$ ett sammanhang $i$ just den här tiden.

\section{Levande forskning- ett sätt att artikulera och utveckla kunskap}

I den finländska reviderade nationella läroplansgrunden omfattar utbildningens värdegrund (LP 2014/2016, s. 13) bland annat följande:

Den grundläggande utbildningen bygger på övertygelsen om att barndomen har ett egenvärde. 
Den grundläggande utbildningen ska stödja elevernas utveckling till humana människor som strävar efter sanning, godhet, skönhet samt rättvisa och fred. I denna utveckling är motsättningar mellan strävan och rådande verklighet oundvikliga. Bildning innebär bland annat att kunna hantera dessa motsättningar på ett etiskt och empatiskt sätt och våga försvara det goda.

Det här valda avsnittet ur den reviderade läroplansgrunden, det vill säga en del av den allmänbildande grundskolans värdegrund, formade min planering av en kurs i bildkonst för klasslärarstuderande hösten 2016. Artikeln är ett resultat av den process som kursen omfattade för mig som konstnär och lärarutbildare och för de studerande som deltog i kursen. Då en reviderad läroplan träder i kraft för grundskola skapar förändringen även rum för reflektion av beprövad hållbar teori och praktik i utbildning. Samtidigt skapas rum för att ändra på invanda mönster, ohållbara strukturer och föråldrade förhållningssätt till undervisning och lärande. En reviderad läroplan och de nya riktlinjer som grundskolan ska arbeta utgående från och mot, fungerar utöver att visa på riktlinje, också inspirerande. Det avsnitt jag citerar inspirerade mig som lärarutbildare. Mer specifikt var det orden elevernas utveckling till humana människor som strävar efter sanning, godhet, skönhet samt rättvisa och fred som jag blev inspirerad av. Det här för att orden väckte ett gensvar i mig, det fanns något jag kände igen som en bekant värdegrund i en samtid som försöker ta sig an alla de utmaningar som den erbjuder. Men en reviderad läroplansgrund fungerar inte endast inspirerande. I och med revidering finns även en form av förväntan på förändring. Hur ett samhälle och en tid beskriver kunskap är beroende av flera faktorer och förändringar innefattar alltid mer komplexa mönster än vad som vid första anblicken blir synligt. Då kunskap kopplas till lärande och bildning blir det uppenbart att förhållningssätt skapas och upprätthålls i en växelverkan mellan olika aktörer. Samtidigt förhandlas olika förhållningssätt och beskrivningar om och om igen. Det är inte fråga om cementerade strukturer utan gränserna för vad som är kunskap, bildning och lärande stretchas hela tiden där verklighet och rådande sanning prövas om och om igen i vad vi känner igen som föreställningar (fantasivärldar) och verklighet. (Jf. Kuhn, 2012)

Den här processen öppnar inom utbildning för en form av kritisk pedagogik som placerar utbildning $i$ en politisk diskurs och lärare som professionella som arbetar med en reflektiv, kritisk praktik och aktivt tar ansvar över att ifrågasätta vad de undervisar, hur de undervisar, vem de undervisar. Då det kommer till didaktisk medvetenhet är det viktigt att lärarstuderande får möjlighet att undersöka de större mål de undervisar för. Henry A. Giroux beskriver i boken On Critical Pedagogy (2011) hur central plats pedagogik har, inte endast i skolan utan i samhället. Giroux pekar på att pedagogik i stor utsträckning är en form av politiskt agerande, då pedagogiskt handlande inte sker i ett vakum utan alltid med en eller flera riktningar i samhället. Läroplansdokument är i sig själva politiska dokument som avspeglar samhällets rådande ramar, strukturer och värderingar. Pedagogik är, då det är sammankopplat med skola och samhälle politiskt även för att det handlar om hur enskilda individer tillsammans lever, skapar och agerar mänsklighet. Också här blir det uppenbart att 


\section{H. Kaihovirta}

det är centralt att som lärarutbildare arbeta med bildning inte endast som en fråga om att socialisera lärarstuderande in i en praktik utan även att arbeta med olika former av redskap för hur lärare ska fungera som kritiska agenter. Att i sina studier få utforska och pröva lärmiljöer där elever får verktyg för att tro på framtiden och deras vilja och medvetenhet om att arbeta för jämlikhet, rättvisa och frihet på ett medvetet och ansvarsfullt sätt är ett sätt att skapa intensitet men och meningsfullhet i lärarstudier.

I artikeln beskriver jag hur bildkonstens didaktik fungerar som en arena och en begreppsvärld för att medvetandegöra studerande om sin kritiska och kreativa kompetens som blivande pedagoger. I mitt didaktiska handlande som lärarutbildare använder jag bildkonsten för att undersöka de olika vägar som lärsituationer kan ta då man arbetar med ett fenomen. Jag söker att observera och artikulera hur lärsituationen i sig själv kan ta sig former av modaliteter där sociala, politiska eller kulturella reproduktioner, ny- och omproduktioner sker. Genom att systematisera dokumentation av arbetets olika faser undersöker jag vilka mönster som i konstbaserade lärprocesser blir till didaktisk medvetenhet, hos mig och lärarstuderande. Utgångspunkten är att konsten erbjuder de resurser jag behöver för att generera lärande, kommunicera det och skapa delaktighet. I de här processerna strävar jag efter att observera de element som kan erbjuda redskap för att våga och vilja bildkonsten som potential för didaktisk medvetenhet hos klasslärarstuderande. Samtidigt strävar jag efter att artikulera de element av hopp, lekfullhet och delaktighet som kommer till uttryck i konstbaserade lärprocesser. Jag söker därmed visa på att pedagogiskt handlande är en praktik av frihet, jag vill visa på hur erfarenheter och kunskap om konstnärliga lärprocesser ger lärarstuderande möjlighet att skapa undervisning på ett annat sätt än jag som lärarutbildare eller de som lärarstuderande tar för givet.

Jag arbetar med att skapa ett ramverk för att lärarstuderande ska förstå bildkonst både som en teoretisk resurs och som en produktiv praktik för lärande och som ett sätt att artikulera mening. Jag strävar efter att stretcha förståelsen av vad bildkonst är, vad bildkonstundervisning är och vad lärande är då det kommer till bildkonst i skolan.

I ljuset av ovanstående beskrivning utmanas föreställningen om att förändring är något som vi måste leva med. Istället vill jag visa på den potential som bildkonst har $\mathrm{i}$ ett pedagogiskt sammanhang. Att lärarstuderande inte bara ska konsumera kunskap för att bli lärare utan att de är medvetna om att de har förmågan att överföra den information och de erfarenheter de får till kunskap som är något utöver det förväntade i sammanhanget.

\section{Projektbeskrivning}

Hösten 2016 genomförde jag kursen Bildkonst som lärmiljö (5sp) för lärarstuderande vid lärarutbildningen Åbo Akademi i Vasa, Finland. I kursen deltog 28 
lärarstuderande (varav 5 internationella studerande tog del via ISEP internationella utbytesprogram för lärarstuderande). Kursens undervisningsspråk var svenska och engelska. De studerande har gett sitt medgivande till att använda materialet (texter och bilder) i artikeln.

Kursdeltagarna informerades vid inledningen av kursen att det var en helt ny kurs även för mig som lärarutbildare. På grund av inbesparingar och omstruktureringar vid universitetet hade hela kursstrukturer lagts om. Jag informerade deltagarna om att kursens grundkaraktär skulle vara experimentell i sitt upplägg och att kursen skulle fungera som en pilot för framtida planering av kursen. Kursupplägget var uppbyggt kring föreläsningar, konstverkstäder, konstdidaktiska verkstäder och konstdidaktiska processer vid två grundskolor som de studerande skulle få vara med om tillsammans med skolornas lärare och elever.

I den här artikeln beskrivs den del av kursen som gick under titeln I CAN FLY. Min plan med den del jag beskriver var att skapa ett rum för transformativt lärande för de studerande. Jag designade didaktiken för kurstillfället så att min förväntan som lärare var att skapa lärsituationer som förändrade de studerandes jagbilder om läraridentitet, samtidigt ville jag skapa en situation där de kunde synliggöra sina jagbilder som möjliga transformerare av lärsituationen.

Kurshelheten bestod av flera sekvenser av konstbaserade processer där temat bearbetades av de studerande. I artikeln artikuleras sekvenserna så att jag artikulerar två perspektiv - ett perspektiv som positioneras av delar av min autoetnografiska dokumentation som konstnär och lärarutbildare. Det andra perspektivet är multimodalt sammanställt av text- och bilddelar av kursdeltagarnas dokumentation av kursen. Syftet är att analysera och tolka de två perspektiven i juxtaposition och på så sätt kunna artikulera kunskap som annars blivit oartikulerad.

Två perspektiv - systematisering av konstbaserade lärprocesser

Här följer en form av juxtapositionering av mina autoetnografiska berättelser och de studerandes beskrivningar och tolkningar under kursen. Det är av vikt att förstå att det genomgående är en fråga om process där alla är delaktiga och för in förståelse för växlingen mellan konstbaserade lärprocesser och bildkonstdidaktisk medvetenhet.

\section{Autoetnografi text 1}

Det är $i$ början av juli 2016 och jag besöker ett fotogalleri i Helsingfors. Fag är $i$ huvudsak intresserad av att se galleriets huvudutställning. På väg ut från utställningen ser jag något som fångar min uppmärksamhet $i$ ett av sidorummen. Det är egentligen en rad med inramade fotografier som vid första anblicken är $i$ det närmaste intetsägande. Fag konstaterar att jag nuförtiden ofta slår på min konstpedagogiska radar då jag besöker konstutställningar. Fotografierna är uppbyggda som montage av bilder som jag tolkar som skärmdumpar, nedladdade bilder och fotografier (eftersom bilderna $i$ övre kanten 


\section{H. Kaihovirta}

har kvar sin balk med information). Bakgrunderna $i$ fotografierna ger intryck av att vara skärmbilder (desktop background). Fust $i$ den stunden översköljs jag av härlig skaparlust. Fag känner hur den känsla av otillräcklighet som jag erfarit då det kommer till digitalisering av bildkonstundervisning viker undan. Fag ser på något sätt en lösning just $i$ de här konstverken. I sammanhanget måste man förstå att utbildningen $i$ Finland under de senaste fem åren artikulerat ett "digi-skutt" som målsättning för utveckling av undervisning. Det här” digi-skuttet” är inspirerande, men har varit absolut omöjligt att genomföra som ett skutt på grund av begränsade resurser $i$ utbildning både vad det kommer till kunskapsresurser, ekonomiska resurser och personresurser. Skuttet har för det mesta kommit till uttryck som ett hopp ut $i$ det okända, eller kanske mer specifikt som ett fritt fall där det har varit svårt att komma på hur skapa kvalitativt innehåll med så begränsade resurser.

Under besöket vid konstutställningen uppkom en bildkonstdidaktisk idé. Fotografierna var uppbyggda så att det som vi digitalt kan tolka som något halvfärdigt, $i$ process (då det kommer till bildproduktion) användes som en estetisk kvalitet. Vidare fanns det en lekfullhet $i$ hur bilder som ligger på varandra $i$ lager på en skärm erbjuder en form av estetik där framför och bakom utnyttjas. Samtidigt är det fullt möjligt att läsa bilderna enligt traditionell läsning av bilder där perspektiv, rum, komposition och symboler tillsammans skapar helheten. Det hela visade sig som en möjlig konstdidaktisk lek med ett fenomen som för de flesta är en vardaglig aktivitet, att ta skärmdumpari ett digitalt bildflöde (här smög sig även en etisk aspekt av bildanvändning in som tankestruktur).

\section{Autoetnografi text 2}

Inspirerad av konstutställningen genomför jag en transfer av idé, en slags nomadisk förflyttning av en erfarenhet som jag för över $i$ ett nytt sammanhang. Fag tänker mig att jag rör mig $i$ ett rhizom där jag pendlar mellan konstupplevelse och att skapa meningsfullt konstpedagogiskt innehåll för lärarstuderande $i$ kursen. Fag stretchar konsten som lärmiljö $i$ min verklighet till att omfatta klasslärarstuderande. Fag har skapat en konstpedagogisk utmaning för de studerande. Fag artikulerar utmaningen som digitala triptyker och jag ger de studerande ett fenomen att undersöka. Fag kallar feomenet "I CAN FLY". De studerande ska arbeta $i$ grupp samt skapa en "didaktisk plan" för hur uppgiften kan göras med elever $i$ årskurs 1-6. De studerande informeras om att de under kursen ska pröva på att göra uppgiften tillsammans med elever.

\section{Perspektiv studerandedokumentation 1}

Här under ett urval av digitala triptyker som de studerande skapade kring fenomenet I Can FLY. I anslutning till bilderna beskrivning av de studerandes intentioner i processen. 


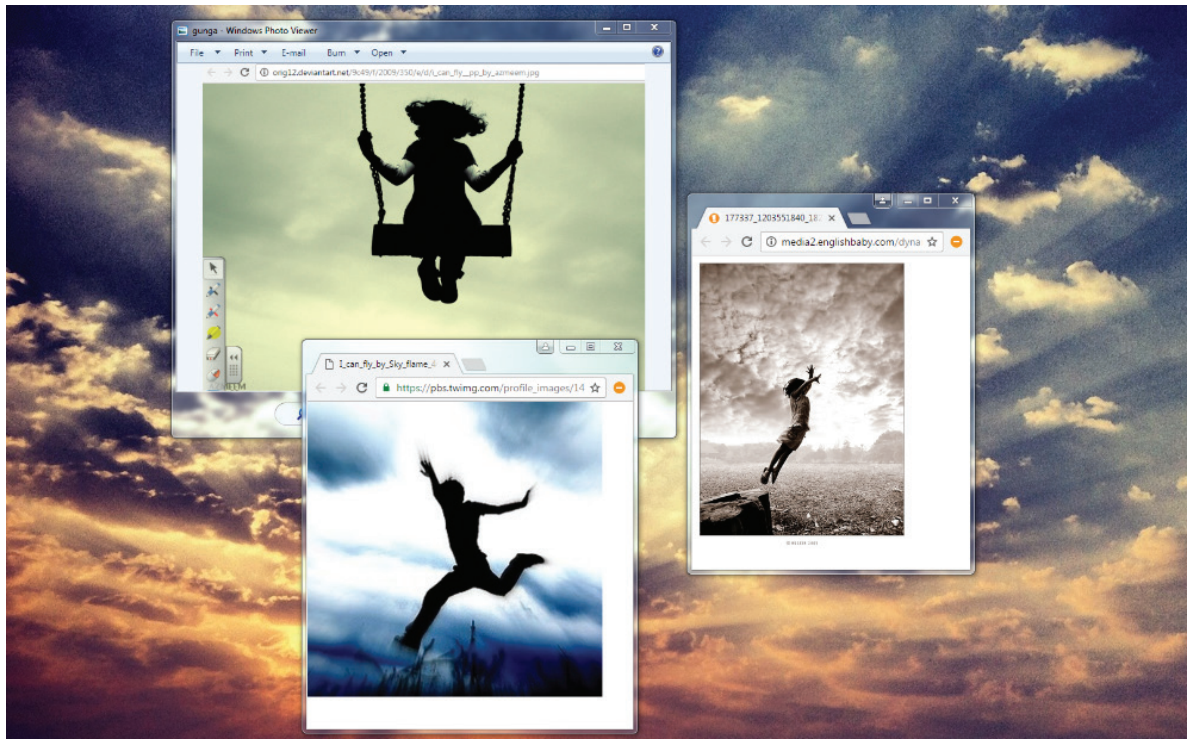

Bilde 1. Free motion.

Vi ville skapa känslan av att kunna flyga, känslan av frihet då man hoppar ett alldeles för långt hopp, då gungan nästan gungar lite för högt eller då man känner $i$ hela kroppen en slags känsla av att kunna lyfta, flyga trots att man inte gör det.

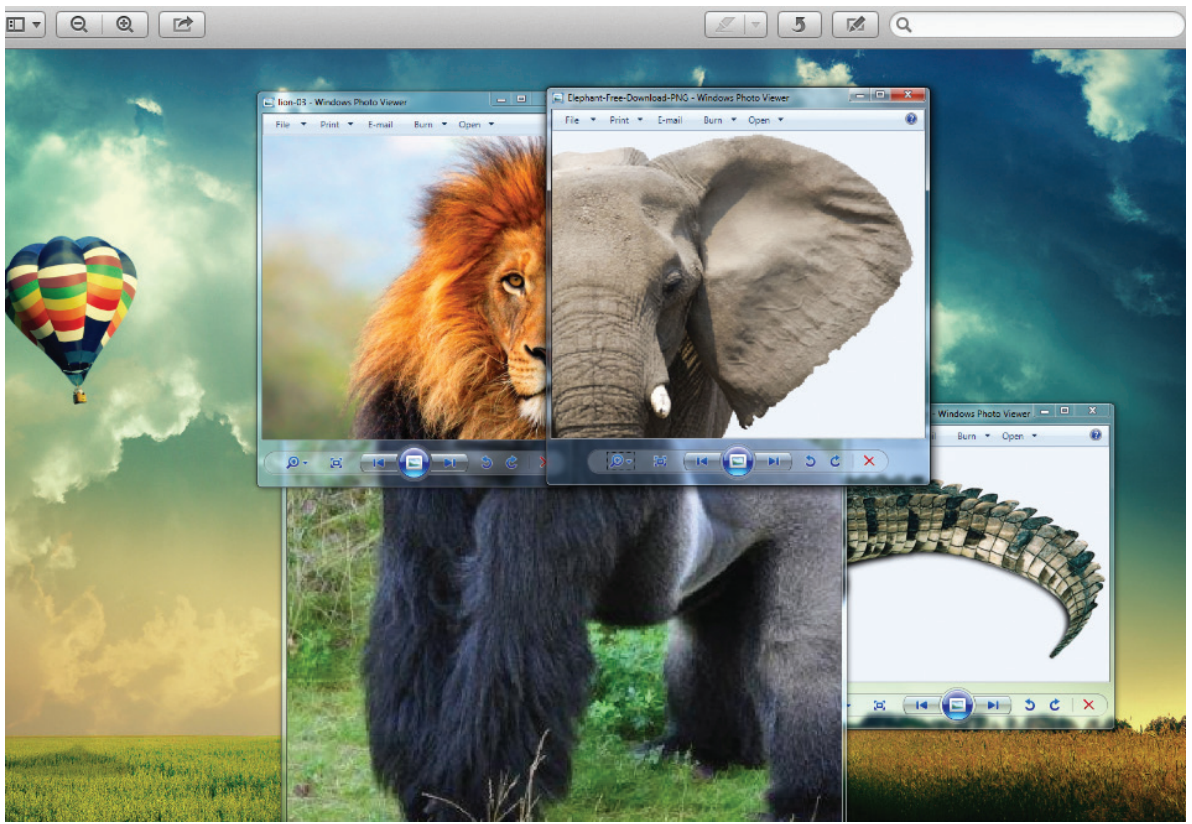

Bilde 2. I have a dream. 


\section{H. Kaihovirta}

Vi tolkade kanske uppgiften lite väl brett, men vi hade så många associationer. Vi ville visa på globalt ansvar, utrotningshotade djur och det blev en slags fantasi kring att flyga $i$ en varmluftsballong över världen.

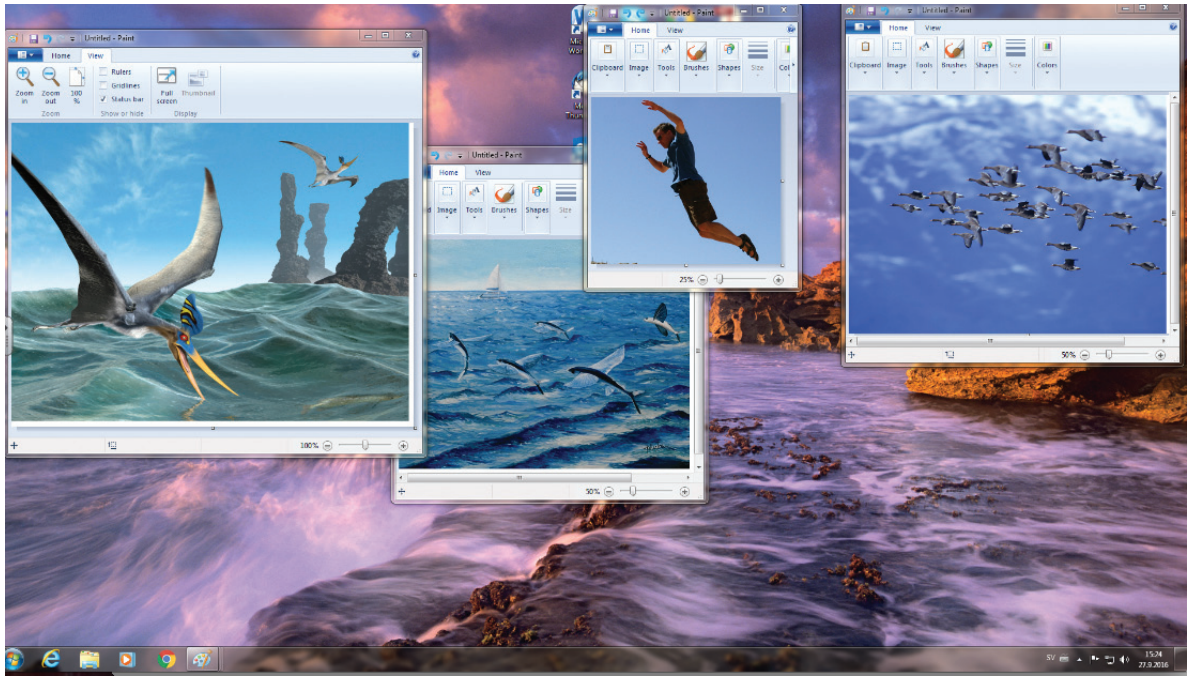

Bilde 3. The Flight.

Av någon anledning blev vi upptagna av blå färg, himmel, hav och bilder som beskriver flygande. Vi ville på något sätt skapa en helhet som visar på den kraft som förmågan att flyga har. Något med luft, vind, fart.

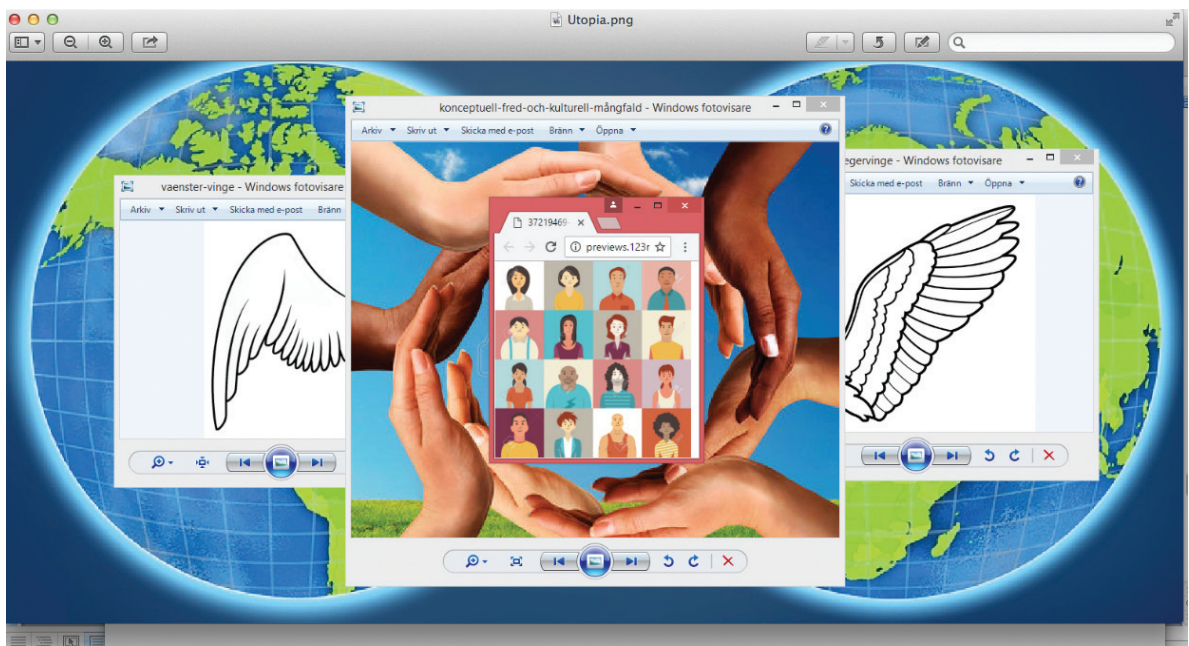

Bilde 4. Utopia. 
Vi ville skapa något om att tanken kan flyga, skapa gemenskap.Vi tänkte oss nästan en informationsplanch, något som vi vill berätta att ska bli verklighet. Att vi kan skapa den verkligheten.

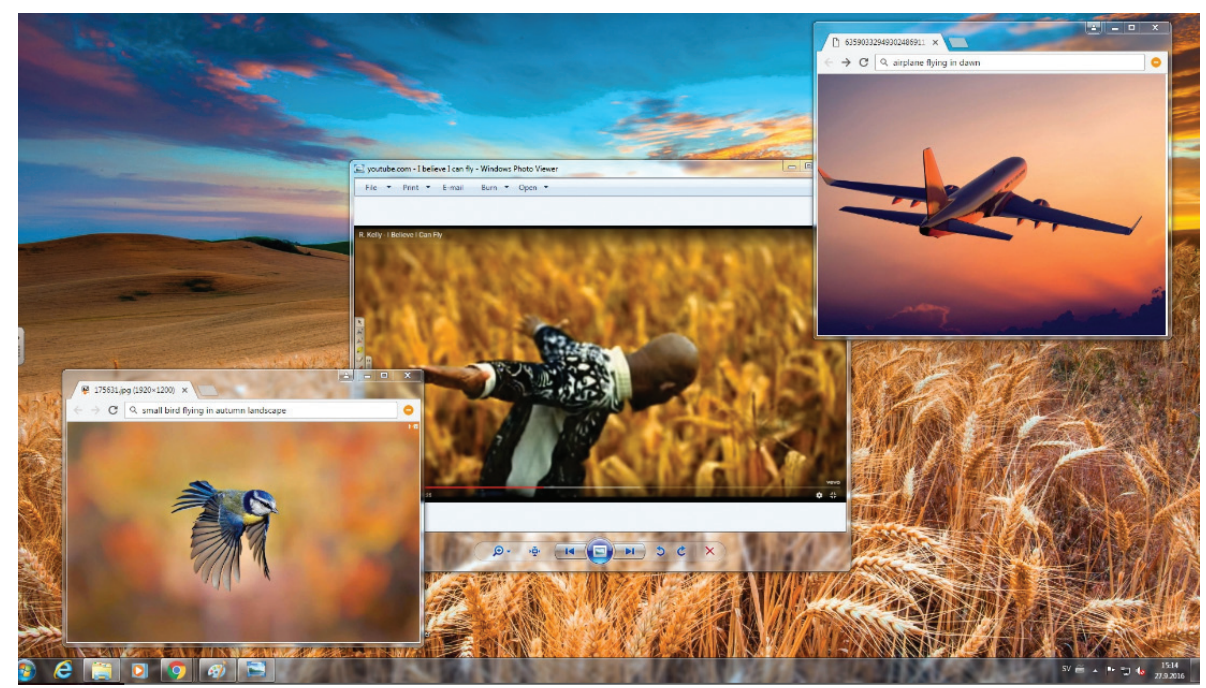

Bilde 5. Flying unities.

Vi lekte med perspektiv, färger och komposition samtidigt som vi ville berätta om olika sätt att förstå flygande. Vi tycker verkligt mycket om hur vi fick ihop en helhet som börjar med ett ivrigt flaxande, sedan känns $i$ kroppen och som sedan skapar en längtan om att flyga iväg.
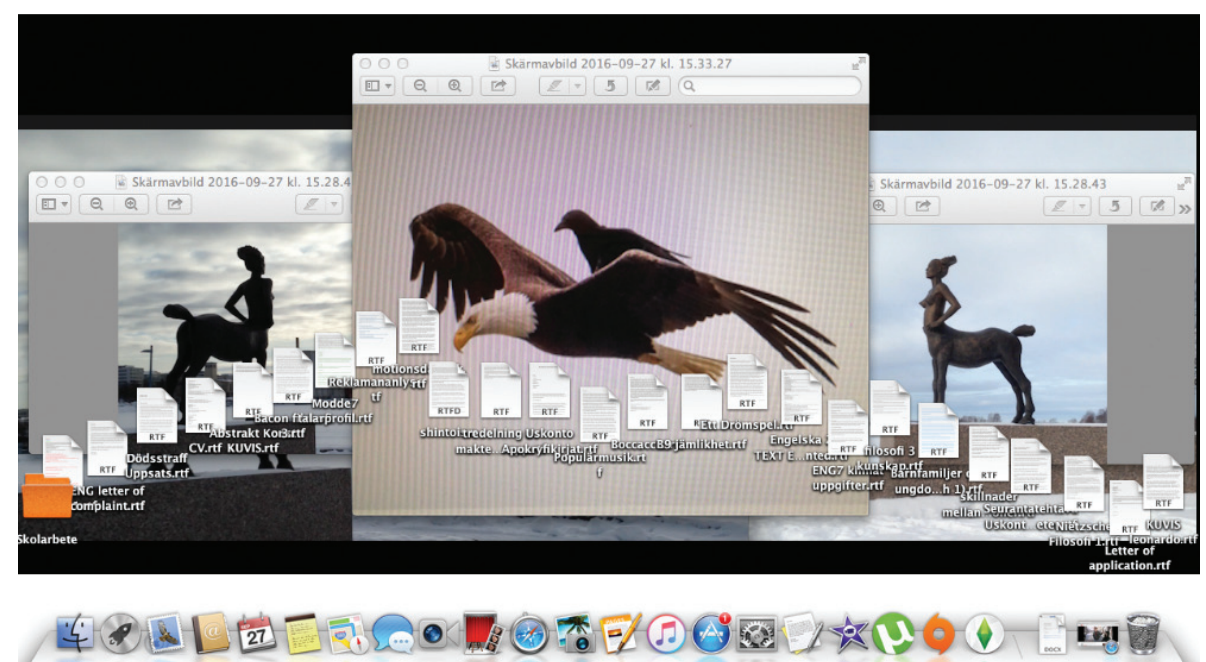

Bilde 6. Flyg \& struktur. 


\section{H. Kaihovirta}

Vi gick verkligen igång på att använda idén om att se allt som ligger på ens arbetsbord (desktop) som visuell kommunikation. Fastän man ser sitt skrivbord flera gånger om dagen, så tolkar man sällan det som en visuell helhet. Man ser det liksom bara som en arbetsyta.Vi berättar också något om kvinnor, män och att få vara fri $i$ sin identitet.

Perspektiv autoetnografi text 3

Fag är imponerad av de artefakter och beskrivningar som de studerande delar med sig. Fag känner dem inte än, kursen tar sin ansats $i$ det de skapat och de är själva mycket glada över hur intressanta och olika tolkningar de gjort. De uttalar upprepade gånger hur inspirerande det är att en till synes enkel ingång till konstnärlig process kan öppna så många spår då man skapar tillsammans. Fag blir också väldigt inspirerad och ser fram emot följande arbetspass.

\section{Perspektiv autoetnografi text 4}

Vid följande arbetspass har jag planerat att de studerande ska lära sig grunderna $i$ måleri. Samtidigt vill jag visa dem möjligheten att själv skapa "läromedel" en iscensättning för att arbeta med ett tema som är högaktuellt då det kommer till bilder $i$ vår samtid. Det handlar om att bli medveten om vad selfies är, vad fenomenet kan användas till och hur man kan arbeta med jagbild, att fotografera sig själv och andra och respekten kring hur de här bilderna delas med varandra.

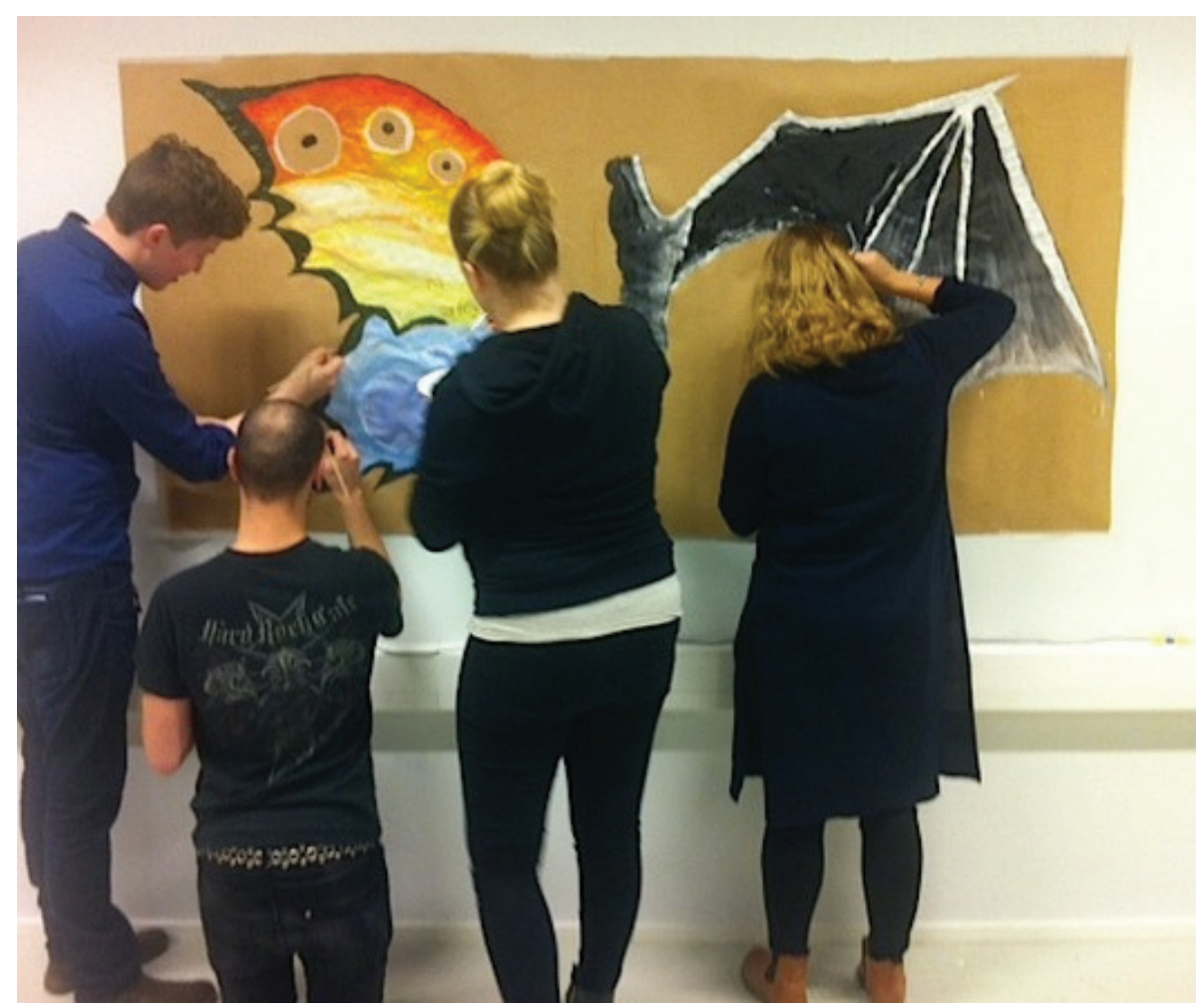

Bilde 7. Studerande skapar vingparet fjäril - drake som bakgrund för selfie. 
Perspektiv studerandedokumentation 2

De studerande arbetar med att skapa vingar som ska bli bakgrunder för den uppgift de kommer att göra tillsammans med elever. De studerande har nu förberett två uppgifter som de ska pröva tillsammans med elever. Den ena uppgiften är "Digital triptyk". Den andra uppgiften är "Fagbilder och dubilder".

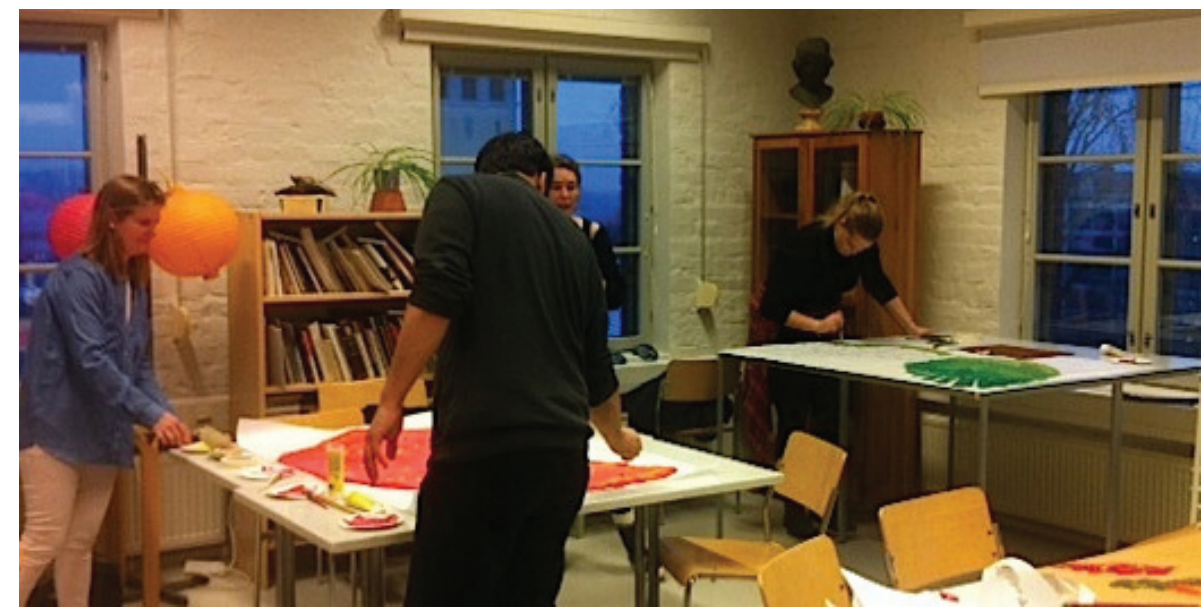

Bilde 8. Studerande skapar olika vingkaraktärer för arbete med selfie.

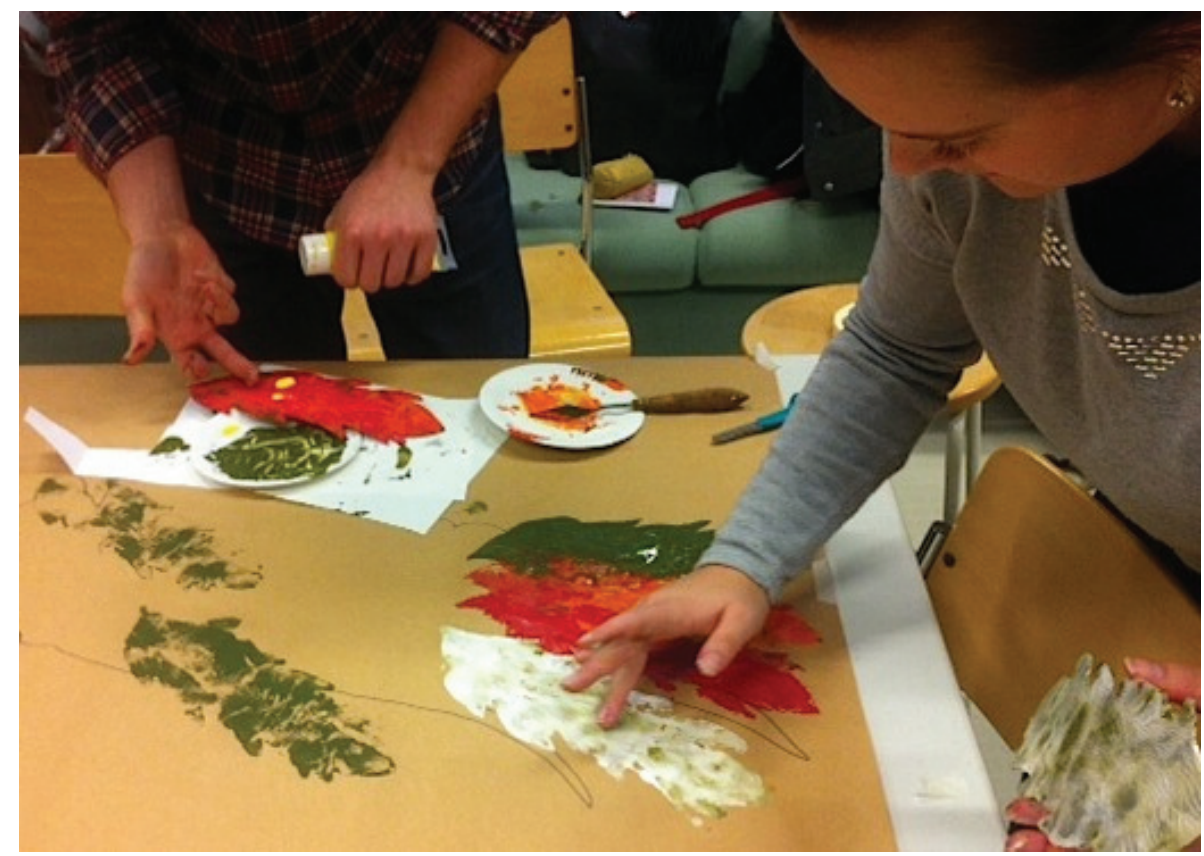

Bilde 9. Studerande skapar vingpar, undersöker måleriets möjligheter. 


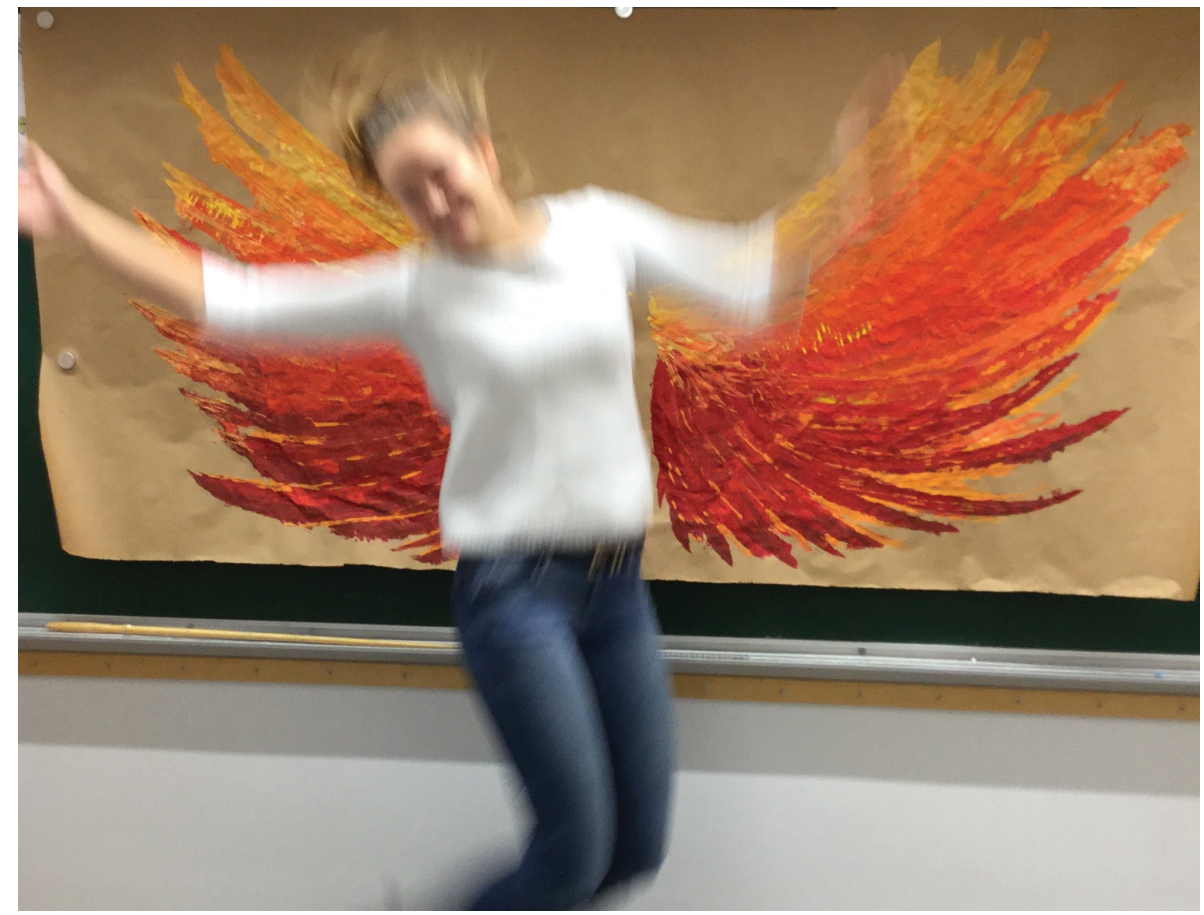

Bilde 10. Studerande testar hur arbeta med "jagbild-du-bild"

\section{Perspektiv autoetnografi text 4}

Följande moment $i$ de studerande konstbaserade lärprocess är att de genomför de båda konstdidaktiska helheterna de skapat tillsammans med elever som går $i$ årskurs 4. Klassen de prövar sina konstdidaktiska planer $i$ består av 20 elever och både jag som deras utbildare och elevernas lärare deltar i lärsituationen. Tillfället är inte utformat utgående från de modeller som används inom kursen för lärarpraktik utan utformas som en studie $i$ bildkonstdidaktisk erfarenhet tillsammans med elever.

\section{Perspektiv autoetnografi text 5}

Efter helheten med arbetet kring temat I CAN FLY där jag prövade hur jag kan erbjuda klasslärarstuderande möjlighet att förstå de möjligheter som konstbaserade lärprocesser har för att skapa konstdidaktisk medvetenhet och kompetens skapade de studerande tillsammans en konstutställning över sin produktion. I samband med utställningen diskuterade de sina erfarenheter samt bjöd medstuderande att ta del av utställningen. Lärprocessen avslutades med reflektionstexter om lärande och möjliga utvecklingstankar.

\section{Perspektiv studerandedokumentation 3}

I samband med utställningens upphängning skapar studerande även en haschtag för instagram. De är engagerade och visar att de vill föra hela processen till slut med en konstnärlig medvetenhet. De studerande artikulerar hur fascinerande det är att se 


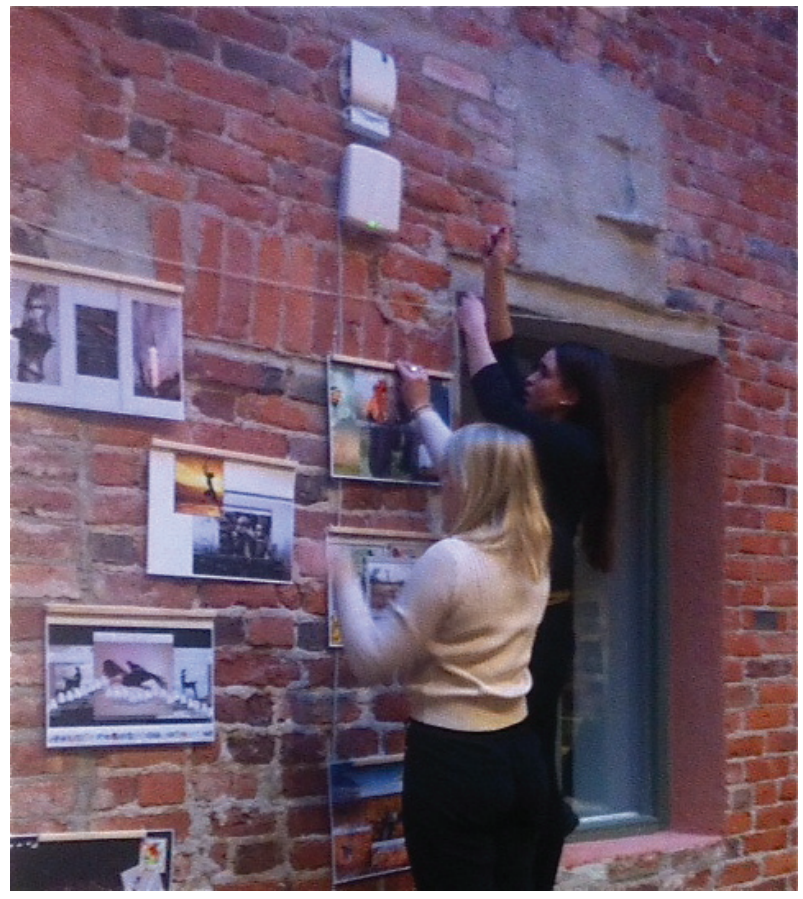

Bilde 11. Upphängning av verk.

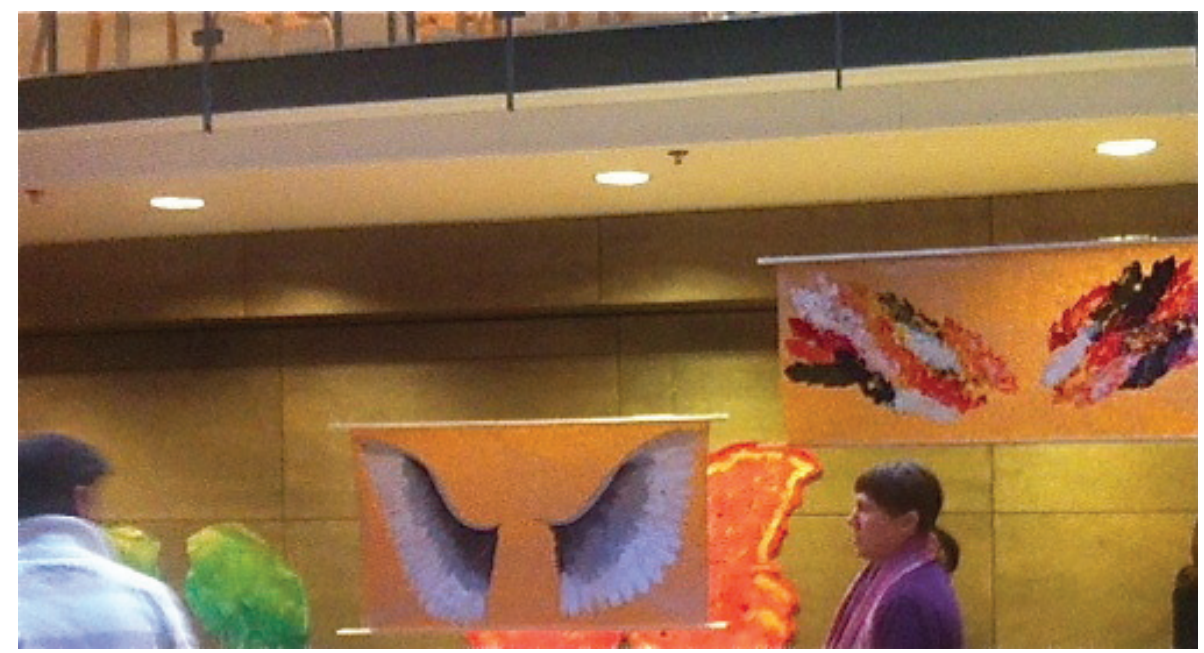

Bilde 12. Upphängning av verk.

deras alster i olika sammanhang och hur betydelserna stretchar och förändras, fördjupas, blir mer omfattande och till och med ibland försvinner beroende på sammanhanget. Det här har de inte varit medvetna om tidigare, "eftersom vi inte sett våra alster som vi skapat i flera olika sammanhang utan endast på en klassrumsvägg" konstaterar en av kursdeltagarna. De uttalar än en gång sin förundran över hur man med enkla medel kan skapa konst som känns meningsfullt och värdeladdat för dem. 


\section{H. Kaihovirta}

\section{Urval av reflektioner över konstbaserad lärprocess och didaktisk medvetenhet (studerande) \\ Studerande 1}

Observing and learning how to analyze other visual art pieces is a significant part of art education. Visual art is much more than drawing and painting, but the ability to think outside the box and find uniqueness in abstract ideas or images. When each Individuality in a creative learning team would be one, it would make a new art more than one would make it alone. When I made a montage according to the theme with a small group, kids had a great idea that I never thought and make it turn into a wonderful piece.

\section{Studerande 2}

En didaktisk modell som man lätt kunde tillämpa i bildkonst ämnet är den didaktiska triangeln där elever och lärare jobbar tillsammans med ämnet som då $i$ detta fall är bildkonsten. Här jobbar alla tillsammans och man fär utvecklas som individ $i$ sin egen takt. Man tar hänsyn till varandra och alla jobbar mot samma mål. Lärare ska låta eleverna få använda sig av sin fantasi och låta eleverna vara de konstnärer som de är.

\section{Studerande 3}

Dokumentationen är viktig både för eleverna, lärarna och elevernas föräldrar. Sedan har jag också lärt mig hur viktigt det är att ställa frågor $i$ klassrummet. Frågor som för eleverna $i$ rätt riktning och skapar tankar och funderingar $i$ deras egna huvuden. Att tillsammans med enskilda elever och hela gruppen ständigt kommunicera konst och ha en öppen miljö där alla tankar och frågor är okej. Under förmiddagen $i$ skolan lärde jag mig hur det också är viktigt att vi som lärare kan vara med-konstnärer och skapa tillsammans med eleverna - visa att vi också tycker det är roligt. En annan sak var att det är viktigt att låta eleverna själva få planera och verkställa och inte alltid få en färdig inramad uppgift att följa. Eleverna är så fulla med fantasi och fantastiska ideer - använd dem! Sen var det också givande att få arbeta tillsammans med eleverna $i$ mindre grupper. Då hade man tid att diskutera med dem och ge dem personlig feedback under processens gång.

\section{Studerande 4}

Det är sällan man får möjlighet att ha en lärare per elev. I min grupp var vi två studeranden och två elever. Fag lärde mig hur man stöder och hjälper $i$ smågrupp. Det var skönt att kunna lägga så mycket fokus på eleverna. Fag lärde mig hur man kan uppmuntra eleverna och få dem att tänka och reflektera över arbetsprocessen. Det var kul att fä skapa vingar. fag tror att det skulle vara lyckat att eleverna också skulle få skapa vingar. Genom att skapa vingar funderar de på struktur osv. $i$ vingar.

\section{Studerande 5}

Som lärare är det lätt att man endast fokuserar på fostran och lärande. När jag undervisat $i$ bildkonst har jag själv haft svårt att ta en mer "konstnärlig" roll. Fag är så van vid att $i$ andra ämnen ge eleverna klara instruktioner och lära eleverna hur man ska göra. 
I bildkonst måste man som lärare ta en annorlunda roll. Det är inte läraren som ska ge eleverna kunskap, konsten ska ge eleverna kunskap och insikt. I läroplan 2016 står det att undervisningen $i$ bildkonst ska handleda eleverna att utforska och uttrycka genom konst. Genom konsten utvecklas elevernas förmåga att tänka kritiskt, påverka och förstå.

\section{Studerande 6}

Som lärare vill jag undvika att tillåta vissa saker och undvika andra. Utrymme för unika uttryck. Lita på elevernas egen utforskande takt.Viktiga kom ihåg är öga-hand koordination, observationsförmåga, uttrycka fantasi, kunna tala om visuella saker, long term work, ansvar för sitt eget arbete och sin egen fantasi, ta hand om sig själv, sin omgivning, varandra. Kombinera tidigare oväntade saker, bra flow, bra känsla. Undvik negativitet och kombinera kreativitet, behov och motivation.

\section{Reflektion}

Informerad av Deweys syn på vetenskap, förmågan att pröva och undersöka ett fenomen på ett vetenskapligt sätt (Jf. Dewey, 1999) har jag inspirerad av en hermeneutisk tradition, att gå in med en förförståelse kring ett fenomen, och sedan undersöka det genom att se de mönster som kan vara möjliga att se sig sträckas utöver min förståelsehorisont, sökt artikulera och förstå konstbaserade lärprocesser som lärarstuderandes förståelse konstdidaktiska möjligheter. Jag har sökt att använda lärarens, konstnärens och forskarens blick för att fånga upp de kvaliteter som kommer fram $\mathrm{i}$ processen. Jag har haft som utgångspunkt att det är själva erfarandet av hela processen som genererar kunskap då den speglas mot didaktiska förväntningar (till exempel läroplan och tanken om bildning) $i$ arbetet. Jag upptäcker att en central del i det hela är användbarheten av det som genereras i arbetet. Den erfarenheten står givetvis som en betydelsefull insikt av de mönster som framkommer och kan gestaltas vidare till nya erfarenheter av att handla, av att tänka och förhålla sig som lärare och utbildare. Att autoetnografiskt följa det utvecklingsarbete och de intentioner jag har i skapandet av konstbaserade lärprocesser formas hela tiden av att jag ser, analyserar och tolkar jag förmår se och att jag inte ser, analyserar och tolkar annat. Växelverkan mellan de olika rollerna leder till att syftet med att vara konstnär, syftet med att vara forskare och syftet med att vara forskare och konstnärer sammanslagna i en systematisk process leder till ny insikt genom longitudinella processer.

För att känna igen de mönster som stiger fram i det material och data som tar form lånar jag en struktur från PAR-metoden (Participatory Action Research) (FisherYoshida, 2009). Det här är en form av metoden. Metoden används för att synliggöra processer i deltagarkultur och för att synliggöra den kraft deltagarna i en lärprocess själva har för att förändra sin kunskapsram och samtidigt själva artikulera förändringen. Modellen består av fem nivåer:

1. Starta med deltagarerfarenheter.

2. Skapa och söka mönster. 


\section{H. Kaihovirta}

3. Lägga till ny mening, information och nytt innehåll.

4. Praktisera förmågor, testa och agera.

5. Pröva i ny praktik.

Läser man av den process som genomförts i kursdelen I CAN FLY kan de fem nivåerna kännas igen i kursdelens ansats, förväntan och ingång i arbetet. Det som utmanar hur synliggöra deltagarerfarenhet är att jag ger en konstnärlig impuls, en utmaning till de studerande att arbeta med för att få syn på sina erfarenheter. Den artikuleras i en visuell uppgift, genom bilder och metareflektioner i text. De mönster som skapas är igenkännbara då de styrs av en konstdidaktisk intention från mig och en konstdidaktisk inställning och förväntning från studerande. Deltagarkulturen är formad av att de studerande är införstådda i arbetssättet. Materialet visar på att det finns en friktion mellan det önskade bildningsperspektivet - det öppna målet och ett mer specifikt mål om professionsutveckling i kursen. För att motverka, eller kanske inspireras av friktionen laborerar jag som lärare med begreppet I CAN FLY, ber de studerande leka och pröva begreppet ur olika perspektiv. Det här för att utmana till att tänka konstdidaktiskt på så många sätt som möjligt. De studerande praktiserar och prövar. De förbereder sig för hur arbeta tillsammans med elever. De skapar konstdidaktiskt material och omarbetar efter egna tankemönster och målsättningar. De påtalar och reflekterar under kursen att de gärna skulle föra över en del av det de förbereder till direkt arbete med elever. De prövar sina erfarenheter och omformar dem till arbete med elever. De arbetar fram en utställning kring temat. De är deltagare $i$ en process som inte endast handlar om att utveckla konstdidaktisk medvetenhet. Det handlar i lika stor utsträckning om att pröva och transformera det som sker under kursen. Det handlar om att de är kunskapande, kritiska och kreativa. Så blir de agenter för konstdidaktik i sitt framtida lärarskap.

\section{Sammanfattning}

Artikelns syfte är att förstå hur konstbaserade lärprocesser kan komma till uttryck som lager på lager av konstupplevelser i en konstdidaktisk process. Juxtapositioneringen av mina intensioner som lärarutbildare, hur jag bygger upp konstnärliga föreställningsvärldar, för de studerande visar på flera insikter om de mönster som man kan se i min undervisning. Jag ser att jag har höga krav på konstnärlig kvalitet, då det handlar om materialkännedom, känslighet för färg, komposition och visuellt berättande. Jag arbetar mycket för att studerande ska "leka på allvar", gå på djupet med vad de skapar. Jag visar respekt för de världar de skapar, deras visuella uttryck och de visuella berättelser de skapar. Det är tydligt att jag är influerad av att lärsituationerna är en form av "situerade konstupplevelser" för de studerande. Samtidigt visar jag hela tiden på pedagogiska frågor, jag arbetar med ämneskunskap och konstdidaktisk medvetenhet. Jag stretchar på situationen så att deltagarna kan artikulera den konstnärliga upplevelsen som en möjlig didaktisk medvetenhet. Jag kan se att jag försöker ge de 
studerande möjlighet att "få en intensiv konstbaserad upplevelse" som jag förväntar mig att de ska klara av att föra över i en didaktisk medvetenhet. Tidsspannet är kort och jag sätter ribban högt. Jag litar på att de studerande nomadiskt kan föra in den kunskap de erövrar i sin helhet i lärarutbildningen i bildkonstundervisningen. Jag litar på att de har kunskap om hur överföra och transformera kunskapen med hänvisning till andra didaktiska kurser de har. Samtidigt som de hela tiden ska försöka förstå och skapa mening kring konstens betydelse i deras framtida undervisning förväntar jag mig att de kan artikulera sin erfarenhet.

En viktig insikt som en av de studerande lyfte fram, och som i förlängningen visar på att den studerande är trygg i sitt förhållningssätt till vad konst kan vara $\mathrm{i}$ förhållande till undervisning, är reflektionen från den studerande: "Det var kul att få skapa vingar. fag tror att det skulle vara än mer lyckat att eleverna också skulle få skapa vingar."

Jag inser som lärarutbildare att jag än mer tydligt och nyanserat hade kunnat arbeta med de studerande kring hur deras eget skapande skapar en didaktisk trygghet i att arbeta tillsammans med eleverna.

Sammanfattningsvis kan jag se att de ledande konstdidaktiska mönster och figurer jag arbetar med är passion, tillit och mångfald i en miljö som för mig är bekant. Genom sin rättframma delaktighet främmandegör lärarstuderande det bekanta och omskapar min intention. De för in sina erfarenheter i en didaktisk medvetenhet som i sig själv skapar förutsättningar för transformation. Artikelns syfte är att förstå hur konstbaserade lärprocesser kan komma till uttryck som lager på lager av konstupplevelser som transformeras till konstdidaktisk medvetenhet hos lärarstuderande. Det blir tydligt att genom kursen så synliggör deltagarna under själva processen ny kunskap genom själva processen. Kunskapen visar sig genom att den skapas under arbetet. Den prövas genom forskningsarbetet.

Genom juxtapositionen har jag artikulerat skillnader och likheter i hur konstbaserade lärprocesser och konstdidaktisk medvetenhet artikuleras olika av människor som är med i processen I CAN FLY. På så sätt hålls målsättningen att växa som människa öppen.

\section{Epilog}

Det var speciellt att genomföra den här konstbaserade helheten som en del av en kurs. De studerande var med om och visade att de var medskapande och delaktiga $i$ att skapa en ny kursstruktur inom lärarutbildning. Under processen framkom flera bra spontana idéer och genom reflektioner ser man tomrum, glapp och utvecklingsmöjligheter. Någonstans långt bak i mitt medvetande fanns följande dikt. Jag tänkte ofta på den under kursen, men läste inte upp den eller delade den med studerande. Det här för att de studerande vecklade ut sina vingar om och om igen. De gjorde det i en lärprocess som artikulerade kunskap genom flera 


\section{H. Kaihovirta}

\section{betydelsebärande element där de uttryckte att de kunde flyga på konstens, tankens och pedagogikens vingar.}

\section{Vingen}

Vi går alla omkring med en vinge

som vi inte kan flyga med

som blir till en börda för oss

som vi måste smyga med.

Vi hade nog kunnat flyga

om inte alla självutnämnda vicevärdar

skolmästare

och alla dom praktiska, taktiska,

nitiska, kritiska,

anemiska, akademiska

felfinnarna med pekpinnarna

hade sagt:

Du kan väl inte flyga!

Håll dig på marken, din envingade jävel!

Och drömmer du ens om att våga

med ett enda vingeslag

pröva din flygförmåga

så tar vi din vinge en dag!

Vi går alla omkring med en vinge, en dröm, en längtan, en sång

Tänk om våra vingar finge

flyga tillsammans en gång!

\section{Kent Andersson}

\section{Författarpresentation:}

Hannah Kaihovirta är filosofie doktor och universitetslektor i estetiska ämnenas didaktik vid den svenskspråkiga lärarutbildningen vid Helsingfors universitet. Hennes forskningsinriktningar är estetiska ämnenas didaktik, samtidskonstens pedagogik på olika utbildningsstadier, digital och multimodal litteracitet i konstbaserad såväl som konstinformerad undervisning. Hon har utvecklat teori om lärandets rhizomatiska aspekter och metoder för dialogundervisning i formella och informella lärmiljöer. En forskningsansats som hon är informerad av är ARTography (Artist, Researcher, Teacher), ett forskningsområde där konsten som erfarenhet och konstens kvaliteter och estetiska ingångar är kärnan i forskningsarbetet. Hennes forskning är representerad i publikationer, föreläsningar, utställningar och internationella forsknings- och utbildningsnätverk. 


\section{Referenser}

Bamford, A. (2006). The Wow Factor. Global Research Compendium on the Impact of the Arts in Education. Germany: Waxmann.

Barone, T. \& Eisner E.W.(2012). Arts Based Research. London, Delhi: Sage.

Barton, G. \& Baguley, M. (Red.). (2017). The Palgrave Handbook of Global Arts Education. London: Macmillan. Dewey, J. (1999). Demokrati och utbildning. Göteborg: Daidalos.

Fisher-Yoshida, B. (2009). Transformative Learning in Participative Processes That Reframe Self-Identity. I B. Fisher-Yoshida, K. D. Geller \& S. A. Shapiro (red.), Innovations in Transformative Learning. Space, Culture, Eo the Arts (s. 65-85). New York: Peter Lang.

Giroux, H. A. (2011). On Critical Pedagogy. New York: The Continuum International Publishing Group.

Kuhn, T.S. (2012). The Structures of Scientific Revolutions. 50th Anniversary Edition. Chicago \& London: Chicago University Press.

Leavy, P.(2015). Method Meets Art. Arts-Based Research Practice (2nd edition). New York, London: The Guilford Press.

Loughran, J. \& Hamilton M. L. (Red.). (2016). International Handbook of Teacher Education, VOL 1. Singapore: Springer.

LP 2014/2016 Grunderna för läroplanen för den grundläggande undervisningen (2004). Helsingfors: Utbildningsstyrelsen.

UNESCO (2006) Road Map for Arts Education. http://www.unesco.org/fileadmin/multimedia/HQ/CLT/CLT/ pdf/Arts_Edu_RoadMap_en.pdf (Lastad 15.04.2017)

Winner, E.,Goldstein, T.R.,Vincent-Lancrin, S. (2013). Arts for Art's Sake. The Impact of Arts Education. OECD publishing. DOI:10.1787/20769679 (Lastad 15.04.2017). 